\title{
GRİP VE AŞI
}

\section{Influenza and Vaccine}

\section{Sedat KAYGUSUZ ${ }^{1}$, Serdar GÜL ${ }^{1}$}

${ }^{1}$ Kırıkkale Üniversitesi Tıp Fakültesi, Enfeksiyon Hastalıkları ve Klinik Mikrobiyoloji A.D., KIRIKKALE, TÜRKIYYE

Grip, influenza virüsleri tarafından gelişen, akut, ciddi ve salgınlara yol açabilen bir enfeksiyon hastalığıdır. Üç tip (A, B ve C) influenza virüsü tanımlanmış olup, İnfluenza A bu tipler içerisinde en ağır seyirli olandır. Hastalık solunum yoluyla bulaşır ve kış aylarında daha sıktır. Pnömoni, en önemli komplikasyonu olmakla birlikte, kardiyak ve merkezi sinir sistemi komplikasyonları da görülebilir. Tanı genellikle klinik olarak konulmakla birlikte, tanıyı desteklemek için moleküler testler de kullanılabilir. Oseltemivir ve zanamivir tedavide kullanılabilecek antivirallerden olup, hastalığın erken evrelerinde kullanıldıklarında hastalığın süresini ve komplikasyon riskini azaltırlar.

Aş1, risk faktörü bulunan kişilerde altta yatan hastalığın daha da kötüleşmesinin, morbiditenin ve mortalitenin önündeki en önemli önleyici seçenektir. Kontrendikasyonu olmayan $\geq 6$ aylı tüm kişiler için rutin yıllık influenza aşısı önerilmektedir. 2018-19 sezonunda da standart dozda, adjuvanlanmamış, inaktif influenza aşıları, üçlü (Trivalan) (IIV3) ve dörtlü (Tetravalan) (IIV4) formülasyonlarda piyasaya sunulmuştur. Üçlü influenza aşılarında A/Michigan/45/2015 (H1N1) pdm09 benzeri virüs, A/Singapur/INFIMH-16-0019/2016 (H3N2) benzeri virüs ve B/Colorado/06/2017 benzeri virüs (Victoria soyu) bulunurken, dörtlü influenza aşıları, bu üç virüs suşuna ek olarak bir influenza B aş1 virüsü olan B/Phuket/3073/2013-benzeri virüs (Yamagata soyu) ile sunulmuştur. Aşıların endikasyonları, kontrendikasyonları ve alınacak önlemler yazıda tartışılmaktadır.

Anahtar Kelimeler: Grip, aşılama, trivalan aşı, tetravalan aşı
Influenza is an acute, severe infectious disease caused by influenza viruses and it can lead to pandemics. Three types of Influenza viruses (A, B and $\mathrm{C}$ ) are determined and type A causes the most severe infection. The disease spreads via respiratory route and occurs commonly in winter. While pneumonia is the most important complication, central nervous system complications can also be seen. The diagnosis is usually established by clinical findings but molecular techniques can also be used for supporting the diagnosis. Oseltamivir and Zanamivir are the antivirals used for treatment and they shorten the duration of the disease and decrease the complication risk. Vaccination is the most important tool for protecting the patients with comorbidities from worsening of the underlying disease as well as mortality and morbidity. The vaccine is also recommended annually for everyone $\geq 6$ months of age without contraindications. In the 2018-2019 season, vaccines without adjuvants, inactive influenza vaccines, quadrivalent (IIV4) and trivalent (IIV3) formulations were also launched. While the trivalent vaccine contains, A/Michigan/45/2015 (H1N1) pdm09 like virus, A/Singapur/INFIMH-16-0019/2016 (H3N2) like virus and B/Colorado/06/2017 like virus (Victoria strain), the quadrivalent vaccine contains one more B/Phuket/3073/2013like virus (Yamagata strain), which is an influenza B virus, in addition to these three viruses. The indications, contraindications of the vaccines and the precautions to be taken are discussed in this article.

Keywords: Influenza, prophylaxis, trivalent vaccine, quadrivalent vaccine 


\section{GíRIŞ}

Grip (İnfluenza), İnfluenza virüslerinin etken olduğu, akut, ateşli ve salgınlarla seyreden bir enfeksiyon hastalığıdır. Ateş, halsizlik ve öksürük, hastalığın en sık görülen semptomlarıdır (1).

\section{Tarihçe}

Hastalığın son 400 yll içinde her 1-3 yılda bir salgınlar (Drift yapma özelliği, nokta mutasyon sonucu epidemi) yaptı̆̆ı tahmin edilmektedir (1). Hirsh, 1173-1875 arasında ortalama 2.4 yıl aralıklarla gelişen 299 salgın olduğunu bildirmiştir (2). Bugüne kadar bildirilen dünya genelindeki en büyük salgın (Şift yapma özelliği, yeni virüsün yol açttğı pandemi), 1918-19 yılları arasında gerçekleşmiş ve tahminen 21 milyon ölüme sebep olmuştur (3).

Tablo 1. İnfluenza A, B ve C virüslerinin farklı özellikleri
İnfluenza A virüsü 1933 'te Smith tarafindan (gelinciklerde), İnfluenza B virüsü 1939'da Francis tarafindan ve İnfluenza C virüsü de 1950 'de Taylor tarafından izole edilmiştir (1).

\section{Viroloji}

İnfluenza virüsleri Ortomiksoviridae ailesinden zarflı, negatif polariteli, segmentli yapıda tek sarmal RNA virüsleridir. İnfluenza $\mathrm{A}, \mathrm{B}$ ve $\mathrm{C}$ olmak üzere üç farklı tipe sahiptir. İnfluenza A daha şiddetli ve daha yaygın olmak üzere influenza B ile salginlara ve epidemilere yol açabilmektedir. İnfluenza $\mathrm{C}$ ise sporadik üst solunum yolu enfeksiyonlarına sebep olmaktadır (1). İnfluenza virüslerinin bazı özellikleri Tablo 1'de gösterilmiştir.

\begin{tabular}{|c|c|c|c|}
\hline & İnfluenza A & İnfluenza B & İnfluenza $\mathrm{C}$ \\
\hline \multirow[t]{2}{*}{ Genetik yapı } & 8 gen segmenti & 8 gen segmenti & 7 gen segmenti \\
\hline & 10 viral protein & 11 viral protein & 9 viral protein \\
\hline Doğal konak & $\begin{array}{l}\text { İnsan, domuz, at, kuşlar, } \\
\text { deniz memelileri }\end{array}$ & Sadece insan & İnsan ve domuz \\
\hline Epidemiyoloji & Antijenik şift ve drift & Sadece antijenik drift & $\begin{array}{l}\text { Sadece antijenik drift, birçok } \\
\text { varyant }\end{array}$ \\
\hline Klinik & $\begin{array}{l}\text { Geniş pandemiler, yüksek } \\
\text { mortalite }\end{array}$ & $\begin{array}{l}\text { Sadece yaşlılarda ve yüksek } \\
\text { riskli hastalarda ağır hastalık, } \\
\text { pandemi görülmez }\end{array}$ & $\begin{array}{l}\text { Hafif hastalı mevsimsel } \\
\text { özellik yok }\end{array}$ \\
\hline
\end{tabular}

Virüs yüzeyinde hemaglutinin (HA) ve nöraminidaz (NA) dikenleri mevcuttur. HA, virüsün konak hücresine tutunmasını, NA ise terminal sialik asit molekülünün ayrılmasını katalize etmektedir. İnfluenza A virüsünde en az 16 farklı HA (H1-16) ve 9 farklı NA (NA1-9) tanımlanmıştır (1). İnfluenza B virüsü yapısal olarak İnfluenza A virüsüne benzemesine karşın, antijenik veya genetik varyasyon göstermez, alt türleri yoktur. İnfluenza virüslerinin genomları segmentli yapıda olduğundan aynı hücreyi enfekte eden farklı virüsler arasında segmentler değiştirilebilir (Reasortment) ki bu süreç yeni türlerin ortaya çıkmasına yol açmaktadır. HA veya NA içindeki küçük antijenik değişimlere "antijenik drift" adı verilirken, İnfluenza $\mathrm{A}$ virüsünde $\mathrm{HA}$ ve NA'da daha radikal değişikliklerle meydana gelen daha büyük değişimlere ise "antijenik şift" adı verilmektedir (1). Yeni bir virüs (HxNx) ortaya çıktığında, toplumda bu virüse karşı 
bağışıklık olmadığından pandemi meydana gelebilmektedir.

\section{Epidemiyoloji}

İnfluenza salgınları dünya genelinde sürekli tekrarlanmakta, ciddi morbidite ve mortaliteye neden olmaktadır. Genellikle İnfluenza A H3N2'nin daha s1k etken olduğu yıllarda mortalite daha fazla görülmüştür (4).
İnfluenza özellikle genç ve üretken populasyonda iş gücü kaybına sebep olmaktadır. İnfluenza geçiren bir hastanın beş ila altı gün hareket kısıtlılığı yaşadığı, üç ila dört gün yatak istirahati yaptığı ve yaklaşık üç gün okula, işe gidemediği bildirilmiştir (5). Hastalığın atak hızı gençlerde, mortalitesi ise yaşlılarda daha fazla görülmektedir (6). Bazı risk gruplarında morbidite ve mortalite oranları daha yüksektir (7) (Tablo2).

Tablo 2. İnfluenza komplikasyonları açısından yüksek riskli gruplar (Kaynak 1'den uyarlanmıştır)

Çocuk ve adölesanlarda influenza komplikasyonları için yüksek riskli gruplar

4 yaş altı

Kronik pulmoner (Astım dahil), kardiyovasküler (Hipertansiyon hariç), hepatik, hematolojik, renal veya metabolik (Diabet dahil) hastalıklar

Bağışıklık sistemini baskılayan hastalık, ilaç tedavisi

Solunum fonksiyonlarını bozan, sekresyonların atılımını zorlaştıran durumlar (Bilinç bozukluğu, nöbet, spinal kord hasarı, nöromusküler hastalıklar)

Uzun süre aspirin tedavisi almak zorunda olmak (Reye sendromu riski)

Kronik bakım merkezinde yaşamak

İnfluenza mevsiminde gebe olma ihtimali olmak

Yetişkinlerde influenza komplikasyonları için yüksek riskli gruplar

65 yaş üstü

İnfluenza mevsiminde gebe olma ihtimali olmak

Kronik pulmoner (Astım dahil), kardiyovasküler, renal, hepatik, hematolojik, metabolik (Diabetes mellitus dahil) hastalıklar

Bağışıklık sistemini baskılayan hastalık, ilaç tedavisi

Solunum fonksiyonlarını bozan, sekresyonların atılmasını engelleyen durumlar

Obezite (Vücut kitle indeksi $>40$ )

Bakım merkezlerinde yaşamak

2009 yılında gerçekleşen H1N1 salgınında, gebeliğin önemli bir risk olduğu açık bir şekilde gösterilmiştir (8). Gebelerin hastaneye veya yoğun bakıma yatış ihtiyacı fazla oranda görülmüştür. Bunun mekanizması net olmamakla birlikte, hormonal değişimin bağışıklık sistemini baskılanması muhtemel sebep olarak düşünülmektedir (9).

Daha önceki salgınlarda risk faktörü olarak gösterilmeyen obezitenin de gripte morbidite ve mortalite riski oluşturduğu gösterilmiştir (10). 


\section{Hastalı̆̆ın Geçişi}

İnfluenza enfeksiyonu geçiren hastaların solunum sekresyonları, bol miktarda virüs içerir. Bunun sonucunda hastalar, öksürdüklerinde veya hapşırdıklarında büyük damlacıklar ( $>5$ mikron) veya aerosol şeklinde virüs yayarlar (11). Damlacıklar havada asılı kalamadığı için damlacık yoluyla bulaş için yakın temas (ortalama $150 \mathrm{~cm}$ ) gerekirken, havada asılı kalan küçük aerosoller daha uzak mesafelere gidebilir (Doğrudan bulaş) (11). Kontamine yüzeylerle temas da bir başka bulaş (Dolaylı bulaş) yoludur. Bir çalışmada, öksürme, hapşırma olmadan nefes alıp vermekle de hastalığın bulaşabileceği gösterilmiştir (12). Transokuler giriş de bildirilmiştir (13). Bu bulaş yollarının klinik önemi henüz net olmamakla beraber, bulaş yolu izah edilemeyen vakaları da düşünmek gerekir.

İnfluenzanın inkübasyonu 1 ila 4 gün (Ortalama 2 gün) arasında değişmektedir (11). Hastaların virüs yaymaya başlaması, semptomların görülmesinden 24-48 saat önce başlar ancak yayılan virüs sayısı semptomatik dönemdekinden çok azdır (14). Ortalama virüs yayma süresi 4.8 gün olmakla birlikte bu süre 7-10 güne kadar uzayabilir (11). Ev içi bulaş sonucu olan sekonder influenza vakalarında virüs atılım süresi daha kısadır ve atılan virüs miktarı semptomların şiddetiyle doğru orantılıdır (15). Yaşlı, kronik hastalığı olan veya bağışıklık sistemi baskılanmış hastalarda virüs atılım süresi daha fazla olabilmektedir $(16,17)$. Bir çalışmada, İmmun kompetan hastalarda virüs atılım süresi ortalama 6.4 gün iken, bu süre bağışıklık sistemi baskılanmış hastalarda ortalama 19 gün olarak bulunmuştur (18). Başka bir çalışmada asemptomatik vakaların hastalık bulaşından sorumlu olmayabileceği ortaya konulmuştur (19). Sistemik glukokortikoid kullanımı, kronik akciğer hastalığı, diyabet gibi komorbiditeleri olan 16 yaş üzeri H3N2 influenza enfeksiyonu geçiren 147 hastanın incelendiği bir çalışmada, viral klerensin daha yavaş olduğu ancak semptomların başlamasından itibaren dört gün içinde oseltamivir tedavisi başlanan hastalarda viral klerensin hızlandığı ve bir hafta içinde virüs atılımının sonlandı $\breve{g}_{1}$ bildirilmiştir (20).

\section{Klinik Belirti ve Bulgular}

Komplike olmayan influenza, kuluçka süresinin ardından ani ortaya çıkan ateş, baş ağrısı, miyalji ve halsizlikle başlar. Daha sonra semptomlara prodüktif olmayan öksürük, boğaz ağrısı, burun akıntısı gibi solunum yolu semptomları eşlik etmeye başlar. Semptomlar geniş bir yelpazede ortaya çıkabilir. Bazı hastalarda soğuk algınlığına benzer semptomlar görülürken, bazı hastalarda da solunum yolu enfeksiyonunu düşündürmeyen sistemik belirti ve bulgular öne çıkabilir. Yaşlı hastalarda semptomlar genel olarak daha siliktir, boğaz ağrısı, miyalji, ateş gibi tipik bulgular gözlenmezken iştahsızlık, halsizlik, güçsüzlük daha belirgin olabilir $(11,21)$.

Laboratuar bulguları genellikle tanıya yardımcı değildir. Lökosit sayısı hastalığın erken döneminde normal veya hafif yüksek iken, hastalığın ilerleyen döneminde rölatif lökopeni görülebilir (21).

Komplikasyon gelişmeyen influenza vakaları genellikle 2-5 gün içinde düzelmektedir. Bazı hastalarda öksürük, halsizlik ve yorgunluk gibi semptomlar birkaç hafta devam edebilir ve bu duruma “postinfluenza asteni” adı verilmektedir (11).

\section{Influenza Komplikasyonlart}

Pnömoni özellikle risk faktörü taşıyan kişilerde en sık görülen komplikasyon iken, kardiyak, kas ve merkezi sinir sistemi ile ilgili komplikasyonları da görülebilmektedir (Tablo2). Pnömoni primer, sekonder (Bakteriyel pnömoni) ya da her ikisi bir arada görülebilir. Primer influenza pnömonisi, virüsün direkt olarak akciğerleri tutması sonucu gelişir ve ağır seyirlidir. Semptomları düzelmeyen, klinik tablosuna dispne ve siyanoz eklenen hastalarda primer pnömoni düşünülmelidir $(21,22)$. Primer pnömoni en ağır komplikasyon olmasına karşın, nadiren görülür. Radyolojik olarak bilateral retiküler ve retikülonodüler 
opasiteler, konsolidasyon alanları, nadiren de alt loblarda fokal konsolide alanlar gözlenir. Sekonder bakteriyel pnömoni de önemli bir komplikasyondur ve genellikle 65 yaş üzeri hastalarda gözlenmektedir (23). $\mathrm{Bu}$ hastalarda semptomların başlangıçta azalırken daha sonra daha sonra ateş, boğaz ağrısı ve pürulan sekresyonun eşlik ettiği öksürüğün eklenmesi tipiktir. Direkt akciğer grafisinde konsolidasyon gözlenir (1).

İnflenza virüsü, solunum epitelini direkt olarak etkileyerek hücreler boyutunda küçülmeye ve siliya kaybına yol açar (1). Bir hayvan modeli çalışmasında influenza virüs ile Streptococcus pneumoniae arasında sinerjizm saptanmış olup, NA aktivitesi arttıkça $S$. pneumonia'nın adezyonunun arttı̆̆ gösterilmiştir (24). $\mathrm{Bu}$ sebeplerden dolayı influenzada sekonder bakteriyel pnömoni riski artmaktadır (24). Sekonder bakteriyel pnömonide en s1k etken S. pneumonia iken, influenza epidemisi olan yıllarda görülme sıklığı artan tek patojen Staphylococcus aureus olarak bildirilmiştir (25).

Hastalarda nadiren primer ve sekonder pnömoni aynı anda görülmekte, ancak varlığı durumunda balgamda hem virüs hem de bakteriyel patojen aynı anda tespit edilebilmektedir (11).

Miyozit ve rabdomiyoliz, influenzanın önemli bir komplikasyonudur ve daha çok çocuklarda görülür. Hastaların çoğunda miyalji görülmesine karşın, gerçek miyozit nadirdir ve tutulan kasta virüs tespit edilebilir (11).

Kardiyak olarak hastalarda sıklıkla elektrokardiyografi (EKG) değişiklikleri gözlenebilir, ancak bu değişikliklerin büyük çoğunluğunun nedeni altta yatan kardiyak hastalığa bağlıdır. Öncesinde kardiyak hastalığg olmayanlarda da geçici EKG değişiklikleri görülebilmektedir (11). Birçok çalışmada influenza ile akut miyokard infarktüsü (AMI) arasında ilişki olduğu gösterilmiştir. Bir çalışmada AMI riskinin hastalığın 13. günlerinde arttığı, daha sonra riskin zamanla azaldığı ve bu riskin 80 yaş üzerinde en fazla olduğu gösterilmiştir (26). Başka bir çalışmada da iskemik kalp hastalığı ve solunum yolu hastalıklarının birlikte görüldüğü hastaların toplumda İnfluenza H3N2 virüsünün yaygın olduğu dönemlerde daha fazla olduğu saptanmıştır (27). İnfluenza hastalarında nadiren miyokardit ve perikardit de görülebilmektedir. İnfluenza hastalığına bağlı ölüm gerçekleşen 29 hastanın otopsilerinin incelendiği bir çalışmada, 20 hastada (\%69) miyokard hasar1, 10 hastada belirgin miyokardit tespit edilmiştir. Ancak miyokard dokusunda viral antijen tespit edilememiş olması ile miyokard hasarında virüsün direkt etkisi olmadığ sonucuna varılmıştır (28).

Merkezi sinir sistemi tutulumu ile ensefalopati, ensefalit, transfers miyelit, aseptik menenjit ve Guillain- Barre sendromu görülebilmekle birlikte bu tutulum oldukça nadir olarak bildirilmiştir (11).

\section{Tanı}

Salgın dönemlerinde influenza tanısı klinik belirti ve bulgular ile konulabilir. İnfluenza salgını esnasında 3744 hastanın retrospektif olarak incelendiği bir çalışmada, öksürük ve ateş birlikteliğinin tanıyı destekleyen en önemli gösterge olduğu ve tanıda \%79 pozitif prediktif değerinin olduğu ortaya konulmuştur (29). Salgın dönemleri dışında klinik bulgulara göre tanı koymak zordur ve solunum yolu enfeksiyonlarının çok az kısmından influenza sorumludur (30).

Tanıyı desteklemek için farklı laboratuvar testleri kullanılabilir. Moleküler bir yöntem olan reverse transkriptaz polimeraz zincirleşme reksiyonu (RTPCR), influenza tanısında duyarlılığı ve özgüllüğü en yüksek yöntemdir. Hızlı sonuç verir, influenza virüsünün tipini ve alt tiplerini belirleyebilir. PCR bazlı testler nazoferingeal aspirat, bronkoalveolar lavaj sıvısı, burun ve boğaz sürüntüsü gibi virüs miktarının az olduğu örneklerde de sonuç verebilir. Yirmi dakikadan kısa sürede sonuç verebilen hızlı moleküler testler de geliştirilmiştir ancak bu yöntemler influenza subtiplerini ayırt edemezler (31).

İnfluenza A ve $B$ viral nükleoprotein antijenlerini solunum örneklerinde tespit etmek üzere geliştirilmiş 
ticari hızlı influenza antijen testleri de mevcuttur. Bu testler 15 dakikadan daha kısa sürede sonuç verebilmesine karşın duyarlılığı RT-PCR ile kıyaslandığında çok düşüktür (32). Hızlı antijen testleri virüs atılımının fazla olduğu, enfeksiyonun erken dönemlerinde daha iyi sonuç vermektedir $(33,34)$. Hızlı influenza tanı testleri aşı suşuyla vahşi tip virüsü ayırt edemediği için canlı atenüe influenza aşısı yaptıranlarda 7 güne kadar yanlış pozitif sonuçlar gözlenebilmektedir (35).

Direkt ve indirekt immunoflorasan antikor testi de tanıda kullanılabilen bir başka yöntemdir. Saatler içerisinde sonuç verebilmesine karşın, duyarlılık ve özgüllüğü viral kültürden daha azdır. Solunum epitel hücrelerine ihtiyaç duyduğu için örnek kalitesi ve uygulayan laboratuvarın deneyimi de önemlidir (36).

İnfluenza virüsü nazal yıkama, boğaz sürüntüsü, bronkoalveolar lavaj veya balgam örneklerinden kültüre edilebilir. Bir çalışmada virüsü izole edebilmek için balgam ve nazal yıkama örneklerinin boğaz sürüntüsü örneklerinden üstün olduğu gösterilmiştir (37). Viral kültür tanıda altın standart olmasına karşın, 48-72 saatte sonuç verdiğinden başlangıçta tanı koymaktan ziyade doğrulama testi olarak veya sürveyans amaciyla kullanılır (1).

Serolojik yöntemlerden enzim linked immuno assey (ELISA), hemaglutinasyon inhibisyon veya kompleman fiksasyon testleri de tanıda kullanılabilir. Ancak tanı koyabilmek için akut dönemde ve 10-14 gün sonra iki örnek alınıp 4 kat antikor artışının gösterilmesi gerekir. Bu nedenle akut hastalık tanısında değil araştırma amacıyla kullanılabilir (1).

İnfluenza enfeksiyonu düşünülen her hastaya tanısal testler yapmak gereksizdir. Eğer yapılan testin sonucu hastaya verilecek tedaviyi veya uygulanacak enfeksiyon kontrol önlemlerini etkileyecekse test yapılmalidir (38).

İnfluenza sezonunda aşağıdaki hasta gruplarına tanısal test yapılmalıdır;
- İnfluenza komplikasyonları açısından yüksek riskli olup (Tablo2) semptomların başlamasından sonra ilk beş günde başvuran hastalar

- Hastalığın başlangıç süresine bakılmaksızın immünsüprese hastalar

- Hastalığın başlangıç süresine bakılmaksızın hastanede yatan ve akut ateşli solunum yolu hastalığ1 olan hastalar (toplum kökenli pnömoni tanısı olan hastalar da dahil)

- Sonuçlar lokal sürveyans verileri için gerekliyse.

Yılın herhangi bir döneminde de aşağıdaki hasta gruplarına tanısal test yapılmalıdır;

- Sağlık çalışanları, bakım merkezlerinde kalanlar, influenza salgını olan bir bölgeden gelenler

- İnfluenza virüslerinin dolaştığı bölgelerden gelen göçmenler ve gemi yolcuları

Bir bölgede influenza salgını varlığında, altta yatan hastalığı olmayıp solunum yolu enfeksiyonu belirti ve bulguları ile hastaneye ayaktan başvuran hastalara tanısal test yapılmayıp, tanının klinik olarak konulması daha doğrudur (39).

\section{Tedavi}

Hastaneye yatışı gerektiren ağır hastalığı olan, alt solunum yolu enfeksiyonu bulunan ve komplikasyon gelişmesi açısından yüksek riskli olan hastalara antiviral tedavi başlanmalıdır (39) (Tablo 2).

Tedavide kullanılabilen üç sınıf antiviral mevcuttur. NA inhibitörleri (Oseltamivir ve zanamivir) ve selektif endonükleaz inhibitörü (Baloksavir) İnfluenza A ve B’ye karşı etkili iken, adamantanlar (Amantidin, rimantidin) ise yalnızca İnfluenza A'ya karşı etkilidir.

Hastalarda semptomlar başladıktan sonra 48 saat içinde başlanan NA inhibitörü tedavisinin semptomların süresini 1-3 gün azalttığ1, 48 saatten sonra başlanan tedavinin genellikle faydasız olduğu gösterilmiştir (39). Hafif-orta şiddette influenza enfeksiyonu olan, yüksek risk grubunda olmayan 65 yaş altı hastalara rutin olarak tanısal test yapılması veya antiviral tedavi başlanması 
önerilmemektedir (40). Tedavi endikasyonu olan hastalarda tedaviye başlamak için test sonuçları beklenmemelidir. (39).

Tedavide genellikle birinci seçenek olan ilaç grubu NA inhibitörleridir. Oseltamivir, günde $2 \mathrm{kez} 75 \mathrm{mg}$ oral yoldan kullanılmaktadır. Zanamivir ise günde $2 \mathrm{kez} 10$ mg inhalasyon şeklinde kullanılmaktadır. NA inhibitörlerini daha yüksek dozda kullanmanın etkinliği gösterilememiştir. Ancak yoğun bakımda yatan hastalarda daha yüksek doz düşünülmelidir. Önerilen tedavi süresi ise 5 gündür $(39,41)$. Adamantanlara karş1 dünya genelinde yüksek düzeyde direnç bildirildiği için bu grubun ampirik tedavide kullanılması önerilmemektedir (38). Oseltamivir dirençli suşlar ilk kez 2007 y1lında tespit edilmiş olup, 2009 yılında Amerika Birleşik Devletleri’nde direnç oranı \%1 olarak gösterilmiştir (42).

2009 yılındaki H1N1 salgınında hastalığın gebelerde çok daha ağır seyrettiği ve komplikasyon riskinin çok yüksek olduğunun ortaya konmasından itibaren influenza enfeksiyonu olan gebelere mutlaka antiviral tedavi önerilmektedir (39).

Kombinasyon tedavisinin monoterapiye üstünlüğü gösterilememiştir ve kombinasyon tedavileri önerilmemektedir (43).

İnfluenza tedavisinde glukokortikoidlerin rolü tartışmalıdır. Bu konuda yapılan bir meta-analizde, glukokortikoidlerin faydasının olmadığı gibi mortalite riskini artırdıkları da gösterilmiştir $(43,44)$.

Hastalarda semptomları azaltmak için asetaminofen veya nonsteroid antiinflamatuar ilaçlar kullanılabilir, ancak özellikle çocuklarda nadir de olsa erişkinlerde Reye sendromuna yol açabileceği için salisilatlar kullanılmamalıdır (39).

Hastalığın yayılmasını önlemek için influenza tanısı konulan ayaktan hastalar, semptomları düzelinceye kadar evde kalmalı, okuldan, işyerinden ve kalabalık ortamlardan uzak tutulmalıdır. Yapılan bir çalışmada el hijyenine uyum ve maske kullanımının ev içi bulaşıc1lığı önlediği gösterilmiştir (45).

\section{GRIP AŞISI}

Her grip sezonu değişim gösteren virüs ve duyarlı bireylerin farklılığı nedeniyle grip enfeksiyonu insanları farklı şekilde etkileyebilmektedir. Her yıl salgınlar yaparak iş ve işgücü kaybına, öğrencilerin ders kaybına, özellikle risk grubu bireylerde hastalığın kötüleşmesine ve belli oranda ölümüne yol açabilen grip enfeksiyonundan korunmanın en önemli ve etkili yollarından biri aşılanmadır. Aşılama ile epidemi ve pandemiye neden olabilen influenzanın morbidite ve mortalitesinin azaltılması, sağlık çalışanlarının iş yükünün azaltılması, ekonomik kayıpların azaltılması mümkündür. Hastalığa bağlı birçok komplikasyonun azaltılması (kardiyak sorunlar, akciğer sorunları, vs) aşı ile mümkün olmaktadır. Aynı zamanda aşılama ile sağlık kuruluşlarının iş yükünün azaltılması ve ekonomik kayıpların (Hastaneye ve yoğun bakım ünitesine yatış sayısının düşmesi, komplikasyonlarla mücadele) azaltılması diğer bir kazançtır (45).

Grip aşılaması sadece risk grupları ve gönüllüler üzerinde değil, aynı zamanda sağlık çalışanlarında uygulanmalıdır. Böylece hem sağlık çalışanlarının işgücü kaybının azalması hem de sağlık kuruluşuna başvuran duyarlı bireyler arasında bulaşıcılığın azaltılması sağlık ve maliyet etkin bir yaklaşım olacaktır. 2018-19 sezonunda ABD'de piyasaya sürülen ve bir kısmı da ülkemizde var olan farklı influenza aşısı formülasyonları Tablo 3'de gösterilmektedir (45) (Tablo 3).

Farklı grip aşıları farklı yaş gruplarında kullanım için onay almıştır. Kimlere hangi aşıların uygulanacağını belirleyen faktörler arasında yaş, sağlık durumu (Şimdiki ve geçmiş) ve grip aşısı veya aşının herhangi bir bileşenine karşı ciddi, yaşamı tehdit eden alerji olarak sayılabilir. İnfluenza aşılarının kullanımına yönelik önlemler Tablo 4'de özetlenmektedir (45). 
Tablo 3: İnflunza Aşıları (ABD, 2018-19 sezonu) (Kaynak 45’den uyarlanmıştrr)

\begin{tabular}{|c|c|c|c|c|c|c|c|c|}
\hline $\begin{array}{l}\text { Jenerik } \\
\text { (Ticari) Adı }\end{array}$ & Sunum & $\begin{array}{c}\text { Yıl } \\
\text { Endikasyonu }\end{array}$ & $\begin{array}{c}\text { HA veya virüs } \\
\text { sayısı/doz (her bir } \\
\text { aşı virüsü) }\end{array}$ & $\begin{array}{l}\text { Üretim } \\
\text { Yeri/şekli }\end{array}$ & $\begin{array}{l}\text { Adjuvan } \\
\text { evet / hayır }\end{array}$ & $\begin{array}{c}\text { Lateks } \\
\text { evet / hayır }\end{array}$ & $\begin{array}{l}\text { Uygulama } \\
\text { Yolu }\end{array}$ & $\begin{array}{c}\text { Tiyomerasol } \\
\text { evet* / hayır } \\
\text { (*clva } \mu g / 0.5 \mathrm{~mL})\end{array}$ \\
\hline \multicolumn{9}{|c|}{ Tetravalan inaktive IIV (IIV4s)**-standart doz-inaktive virüs içerir } \\
\hline Afluria Tetravalan (Seqirus) & $\begin{array}{l}0,5 \mathrm{ml} \mathrm{PFS} \\
5.0 \mathrm{ml} \mathrm{MDV}\end{array}$ & $\begin{array}{c}\geq 5 \text { yıl } \\
\geq 5 \text { y11 (iğne/şırınga) } \\
18-64 \text { y1l (jet } \\
\text { enjektör) }\end{array}$ & $15 \mu \mathrm{g} / 0.5 \mathrm{ml}$ & yumurta & hayır & hayır & $\mathrm{im}$ & $\begin{array}{l}\text { hayır } \\
24,5\end{array}$ \\
\hline $\begin{array}{l}\text { Fluarix Tetravalan } \\
\text { (GlaxoSmithKline) }\end{array}$ & $0,5 \mathrm{ml}$ PFS & $\geq 6$ ay & $15 \mu \mathrm{g} / 0.5 \mathrm{ml}$ & yumurta & hayır & hayır & $\mathrm{im}$ & hayır \\
\hline $\begin{array}{l}\text { Flulaval Tetravalan } \\
\text { (Quebec'in ID Biomedical Corp.) }\end{array}$ & $0,5 \mathrm{ml} \mathrm{PFS}$ & $\geq 6$ ay & $15 \mu \mathrm{g} / 0.5 \mathrm{ml}$ & yumurta & hayır & hayır & im & hayır \\
\hline $\begin{array}{l}\text { Fluzone Tetravalan } \\
\text { (Sanofi Pasteur) }\end{array}$ & $\begin{array}{l}5.0 \mathrm{ml} \mathrm{MDV} \\
0,25 \mathrm{ml} \text { PFS }\end{array}$ & 6-35 ay & $\begin{array}{l}7.5 \mu \mathrm{g} / 0.25 \mathrm{ml} \\
15 \mu \mathrm{g} / 0.5 \mathrm{ml}\end{array}$ & yumurta & hayır & hayır & $\mathrm{im}$ & $\begin{array}{l}<25 \\
\text { hayir }\end{array}$ \\
\hline & $\begin{array}{l}0,5 \mathrm{ml} \mathrm{PFS} \\
0,5 \mathrm{ml} \mathrm{SDV} \\
5.0 \mathrm{ml} \mathrm{MDV}\end{array}$ & $\begin{array}{l}\geq 3 \mathrm{y} 11 \\
\geq 3 \mathrm{y} 11 \\
\geq 6 \text { ay }\end{array}$ & & & & & & $\begin{array}{l}\text { hayır } \\
\text { hayır } \\
25\end{array}$ \\
\hline Flucelvax Tetravalan (Seqirus) & $\begin{array}{l}0,5 \mathrm{ml} \mathrm{PFS} \\
5.0 \mathrm{ml} \mathrm{MDV}\end{array}$ & $\geq 3$ yil & $15 \mu \mathrm{g} / 0.5 \mathrm{ml}$ & hücre kültürü & hayır & hayır & $\mathrm{im}$ & $\begin{array}{l}\text { hayir } \\
25\end{array}$ \\
\hline \multicolumn{9}{|c|}{ Trivalan IIV (IIV3)** - standart doz - inaktive virüs içerir } \\
\hline Afluria (Seqirus) & $\begin{array}{l}0,5 \mathrm{ml} \mathrm{PFS} \\
5.0 \mathrm{ml} \mathrm{MFV}\end{array}$ & $\begin{array}{c}\geq 5 \text { yıl } \\
\geq 5 \text { yıl (iğne/şırınga) } \\
18-64 \text { yıl (jet } \\
\text { enjektör) }\end{array}$ & $15 \mu \mathrm{g} / 0.5 \mathrm{ml}$ & yumurta & hayır & hayır & im & $\begin{array}{l}\text { haylr } \\
24,5\end{array}$ \\
\hline \multicolumn{9}{|c|}{ Trivalan IIV3 - yüksek doz- inaktive virüs içerir } \\
\hline $\begin{array}{l}\text { Fluzone Yüksek Doz } \\
\text { (Sanofi Pasteur) }\end{array}$ & $0,5 \mathrm{ml} \mathrm{PFS}$ & $\geq 65$ y1l & $60 \mu \mathrm{g} / 0.5 \mathrm{ml}$ & yumurta & hayır & hayır & im & hayır \\
\hline \multicolumn{9}{|c|}{ Trivalent IIV3-adjuvanlı - inaktive virüs içerir } \\
\hline Fluad (Seqirus) & $0,5 \mathrm{ml} \mathrm{PFS}$ & $\geq 65$ y1l & $15 \mu \mathrm{g} / 0.5 \mathrm{ml}$ & yumurta & evet & hayır & im & hayır \\
\hline \multicolumn{9}{|c|}{ Tetravalan RIV (RIV4) - rekombinant HA içerir } \\
\hline $\begin{array}{l}\text { Flublok Tetravalan } \\
\text { (Sanofi Pasteur) }\end{array}$ & $0,5 \mathrm{ml}$ PFS & $\geq 18$ y1l & $45 \mu \mathrm{g} / 0.5 \mathrm{ml}$ & rekombinant & hayır & hayır & $\mathrm{im}$ & hayır \\
\hline \multicolumn{9}{|c|}{ Tetravalan LAIV (LAIV4)- Canlı, zayıflatılmış, soğuk adapte edilmiş virüs içerir } \\
\hline FluMist Tetravalan(AstraZeneca) & $0.2 \mathrm{ml}$ nazal & $2-49$ y1l & $\begin{array}{l}10^{6,5-7,5} \text { flüoresan } \\
\text { fokus br/ } 0.2 \mathrm{ml}\end{array}$ & yumurta & hayır & hayır & naz & hayır \\
\hline
\end{tabular}

**Ülkemizde 2015 yılından itibaren mevcuttur

Trivalan aşı: 2 İnfluenza A suşu, 1 İnfluenza B suşu içerir; Tetravalan aşı: 2 İnfluenza A suşu, 1 İnfluenza B suşu içerir.

IIV: inaktive influenza aşısı; LAIV: canlı zayıflatılmı influenza aşısı; RIV: rekombinant influenza aşısı; naz: nazal; im: kas içi; 
Tablo 4: İnfluenza aşılarının kullanımına yönelik kontrendikasyonlar ve tedbirler (Kaynak 45'den uyarlanmıştır.)

\begin{tabular}{|c|c|c|}
\hline Aşı tipi & Kontrendikasyonlar & Önlemler \\
\hline $\begin{array}{l}\text { IIV } \\
\text { inaktive }\end{array}$ & $\begin{array}{l}\text { Aşıının herhangi bir bileşenine karşı veya ya da } \\
\text { herhangi bir influenza aşısı sonrası şiddetli alerjik } \\
\text { reaksiyon hikayesi (anaflaksi gibi ciddi alerjik } \\
\text { reaksiyon) }\end{array}$ & 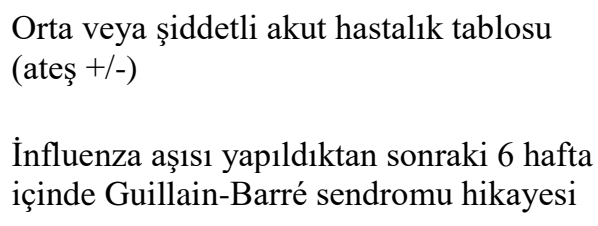 \\
\hline $\begin{array}{l}\text { RIV } \\
\text { rekombinant }\end{array}$ & $\begin{array}{l}\text { Aşıdaki herhangi bir bileşenine karşı ciddi alerjik } \\
\text { reaksiyon hikayesi }\end{array}$ & $\begin{array}{l}\text { Ateşli veya ateşsiz orta veya şiddetli akut } \\
\text { hastalık } \\
\text { İnfluenza aşısı yapıldıktan sonraki } 6 \text { hafta } \\
\text { içinde Guillain-Barré sendromu hikayesi }\end{array}$ \\
\hline \multirow[t]{5}{*}{$\begin{array}{l}\text { LAIV } \\
\text { canlı }\end{array}$} & $\begin{array}{l}\text { Aşının herhangi bir bileşenine karşı veya herhangi } \\
\text { bir influenza aşısı sonrası şiddetli alerjik reaksiyon } \\
\text { hikayesi olanlar (anaflaksi gibi ciddi alerjik } \\
\text { reaksiyon) }\end{array}$ & $\begin{array}{l}\text { Orta veya şiddetli akut hastalık tablosu } \\
\text { (ateş }+/- \text { ) }\end{array}$ \\
\hline & $\begin{array}{l}\text { Eşzamanlı aspirin veya salisilat içeren tedavi alan } \\
\text { çocuklar ve adölesanlar }\end{array}$ & $\begin{array}{l}\text { İnfluenza aşısı yapıldıktan sonraki } 6 \text { hafta } \\
\text { içinde Guillain-Barré sendromu hikayesi }\end{array}$ \\
\hline & $\begin{array}{l}\text { Ebeveynlerin gözlemlediği ve bir sağlık hizmeti } \\
\text { sağlayıcısının } 1 \text { yıl boyunca izlemiyle vizing varlığı } \\
\text { veya astım tanısı almış 2-4 yaş çocuklar } \\
\text { Herhangi bir nedene bağlı olarak immün sistemi } \\
\text { baskılanmış çocuklar ve yetişkinler (ilaçların veya } \\
\text { HIV enfeksiyonunun neden olduğu } \\
\text { immünsüpresyon dahil) } \\
\text { Korunmuş bir çevreye ihtiyaç duyan ciddi } \\
\text { immünsüpresif kişilerin yakın temaslıları ve } \\
\text { bakıcıları }\end{array}$ & $\begin{array}{l}\geq 5 \text { yaş kişilerde astım valığı } \\
\text { İnfluenza enfeksiyonu sonrası } \\
\text { komplikasyonlara yatkınlığı olabilecek } \\
\text { altta yatan tıbbi durumlar } \\
\text { Örneğin, kronik pulmoner, } \\
\text { kardiyovasküler (izole hipertansiyon } \\
\text { hariç), renal, hepatik, nörolojik, } \\
\text { hematolojik veya metabolik bozukluklar } \\
\text { (diyabet mellitus dahil) }\end{array}$ \\
\hline & Gebelik & \\
\hline & Önceki 48 saat içinde influenza antiviral ilaç alanlar & \\
\hline
\end{tabular}

\section{Aşı İçerikleri ve Çeşitleri}

Geleneksel grip aşıları (Trivalan, “üç değerlikli” aşılar) üç influenza virüsüne karşı hazırlanırlar. Bunlar iki influenza A (H1N1 ve H3N2) virüsü ve bir influenza B virüsü içermektedirler. 2018-19 sezonunda uygulanacak aşı suşları A/Michigan/45/2015 (H1N1) pdm09 benzeri virüs, A/Singapur/INFIMH-160019/2016 (H3N2) benzeri virüs ve B/Colorado/06/2017 benzeri virüslerdir (Victoria soyu). Buna ilaveten influenza B'nin görülmesinin artmasıyla beraber "dört değerlikli, tetravalan, kuadrivalan" aşılar da kullanıma girmiş olup ülkemizde de bulunmaktadırlar. Tetravalan aşılar, trivalan aşıya ek olarak ikinci bir influenza $B$ virüsü olan B/Phuket/3073/2013 benzeri virüsü (Yamagata soyu) ekleyerek oluşturulmuşlardır. FDA tarafindan onay alınmış olan bu aşılar yapısal olarak incelendiğinde, üç farklı şekilde yapıldığ 1 anlaşılmaktadır: inaktive (IIV), canlı zayıflatılmış (LAIV), rekombinan (RIV) influenza aşılar $(45,46)$ (Tablo 3). 
İnfluenza aşıları Dünya Sağlık Örgütü aşı komitesi tarafından bir önceki grip mevsiminde elde edilen hâkim suşlara göre oluşturulmaktadır. Aşı içeriklerinin açıklanması Güney yarım küre için Şubat ayı iken, Kuzey yarım kürede bu tarih Eylül ayıdır. Sürveyans verileri gözden geçirilir ve aday aşı virüsleri tartışılır ve FDA tarafindan onanarak ABD piyasasına verilmektedir $(45,46)$. Ülkemizde tetravalan aşıların kullanımına 2014 yılından itibaren başlanmıştır (47).

İnaktive aşı, saf yumurtada üretilen virüslerden elde edilir. İçeriğinde HA ve az miktarda yumurta proteinleri bulunmaktadır.

Canlı aşılar, soğuğa adapte edilmiş trivalan bir aşı olup, önerilen mevsimsel A aşı suşları ile reassorte edilen sub-tip A donör suşunda üretildikten sonra yine reassorte edilen $\mathrm{B}$ virüsü ile birleştirilerek elde edilir. $\mathrm{Bu}$ aşıların önemli özelliği, zayıflatılmış canlı virüslerin sıcağa duyarlı oldukları için nazofarenkste çoğalabilmesi, buna karşın daha sicak ortamlarda (Alt solunum yolların, vücut) çoğalamamasıdır (47).

Rekombinan aşılar ise hayvan hücrelerinde çoğaltılmış virüslerin yalnızca HA proteininin izole edilerek diğer virüs proteinleriyle birleştirilerek çoğaltılmasıyla elde edilirler. Dolayısıyla virüsün ya da çoğaltıldı̆̆ hücrenin herhangi bir materyalini taşımazlar.

Grip aşısı esasen içeriğindeki bir maddeye karşı alerjisi olmayan herkese uygulanabilir. 2012 yılında Dünya Sağlık Örgütü'nün grip aşısı önerileri griple ilişkili komplikasyonların gelişmesi yüksek riskli kişilerden en öncelikli grup olarak hamile kadınlar(ve doğum sonrası iki haftaya kadar olan kadınlar) belirlenirken, 5 yaşından küçük çocuklar (Özellikle $<2$ yaş), $\geq 65$ yaş yetişkinler, huzurevleri ve diğer uzun süreli bakım tesisleri sakinleri şeklinde sıralanmaktadır $(48,49)$.

Aşağıdaki tıbbi rahatsızlıklardan bir ve/veya birkaçına sahip kişiler risk grupları olarak belirlenmiştir;
- Astim

- Nörolojik ve nörogelişimsel durumlar (Beyin, omurilik, periferik sinir ve serebral palsi, epilepsi, felç, zihinsel sakatlık, orta ila şiddetli gelişimsel gecikme, kas distrofisi veya omurilik yaralanması gibi)

- Kronik akciğer hastalığı (Kronik obstrüktif akciğer hastalığı ve kistik fibroz gibi)

- Kalp hastalığı (konjenital kalp hastalığı, konjestif kalp yetmezliği ve koroner arter hastalığı gibi)

- Kan hastalıkları (Orak hücre hastalığı gibi)

- Endokrin bozukluklar (Diyabet gibi)

- Böbrek bozuklukları

- Karaciğer bozuklukları

- Metabolik bozukluklar (Kalitsal metabolik bozukluklar ve mitokondriyal bozukluklar gibi)

- Hastalığa veya ilaca bağlı zayıflamış bağışıklık sistemi ( HIV veya AIDS veya kanser veya kronik steroidler gibi kişiler)

- Uzun süreli aspirin veya salisilat tedavisi alan (Reye sendromu riski) 6-18 yaş çocuk ve adölesanlar

- Aşırı şişmanlığı olan kişiler (Vücut kitle indeksi $\geq 40$ )

- Sağlık çalışanlarıdır.

Tüm risk gruplarındaki kişiler için yaşa uygun inaktive veya rekombinant aşılar uygundur. Yukarıda listelenen bazı gruplar dahil olmak üzere bazı popülasyonlar için canlı atenüe aşı önerilmemektedir (Tablo 4).

Zayıflatılmış canlı aşılar bağışıklık sistemi baskılanmış kişiler için kullanılmamalıdır $(45,50)$. Ancak bu aşılar 2-49 yaş arası gebe olmayan kişiler için yeniden bir seçenek haline gelmiştir (45). 
İnaktive aşılar ve rekombinant influenza aşıları diğer inaktif aşılarla veya canlı aşılarla birlikte eşzamanlı veya ardışık olarak uygulanabilir. Eş zamanlı olarak verilen enjekte edilebilir aşılar ayrı anatomik bölgelerde uygulanmalıdır. Bununla birlikte, canlı bir aşı (LAIV4 gibi) uygulandıktan sonra, başka bir canlı aşı uygulanmadan önce en az 4 hafta geçmelidir (49). Yumurta alerjisi olan kişiler için canlı aşı kullanımı, ACIP tarafından Şubat 2016'da onaylanmıştır. Yumurta alerjisi olan bireylerin 2018-19 sezonunda ise herhangi bir lisanslı, tavsiye edilen ve yaşa uygun grip aşısı (IIV, RIV4 veya LAIV4) alabilecekleri belirtilmiştir $(49,51)$. Aşının koruyucu etkisi, uygulamadan yaklaşık 2 hafta sonra gelişen antikorlarla başlamaktadır. Bu nedenle en uygun aşılama zamanlaması grip mevsiminin en yoğun olacağı tarihlere göre planlanmalıdır. Bu da Ekim ve Kasım ayları olarak tercih edilmelidir. Son yıllarda mevsimlerde yaşanan kaymalar nedeniyle salgın zamanları daha ileri tarihlerde görülebilmektedir. Ülkemiz sürveyans verilerinde hastalık tepe zamanının Ocak sonu - Şubat başı olduğu ve Nisan ayında da vakaların devam ettiği bildirilmiştir. $\mathrm{Bu}$ nedenle salgının henüz başlamadığı Aralık ve Ocak ayı gibi zaman dilimlerinde de aşı yapılabilir. Aşılama süreci dinamik olmalı ve aşılama optimal zamanda yapılmalıdır. Çok erken yapılması etkinliğini azaltabilir. Bir salgın sırasında aşılanmamış kişilere ve özellikle risk gruplarına aşı yapılması, salgına rağmen önerilmektedir. Sağlıklı erişkinlerde koruyuculuğun daha uzun ( $\geq 6$ 6-8 ay), bağışıklığı baskılanmış ve yaşlı kişilerde ise daha kısa ( $\leq 3-4$ ay) olabileceğini gösteren çalışmalar mevcuttur $(52,53)$.

İnfluenza aşısının etkinliği yıldan yıla değişebilir. Bir grip aşısı ile sağlanan koruma, aşıyı alan kişinin yaşına, sağlık durumuna ve aşıdaki virüsler ile dolaşımdaki virüslerin benzerliğine bağlı olarak değişiklik gösterebilmektedir.

\section{Ínaktive (Ölü) İnfluenza Aşıları}

Ülkemizde bulunan inaktive aşılar (Trivalan ve kuadrivalan), 6 ayın üzerindeki kişilere yılda $1 \mathrm{kez}$ yapılır. CDC yeni onay verdiği aşılama programlarında yaşa göre aşılama seçeneklerinde güncellemeler yapmıştır. Çeşitli bireysel inaktive influenza aşıları için yaş göstergeleri farklı olup, sadece yaşa uygun ürünler kullanılmalıdır (Tablo 3) (45,47). Aşılar ülkemizde 0,5 $\mathrm{ml}$ tek dozluk flakonlar olup, adjuvan içermemektedirler ve kas içine uygulanmaktadırlar (Erişkin ve adölesanlarda deltoid kasa).

İntradermal aşılar ise 40 kat daha az antijen içerirler. Bağışıklık oranları ise diğerleri ile denktir. 18-64 yaş aralığı için onay almışlardır (48).

Yüksek doz içeren aşılar (Dört kat daha fazla antijen içerir), yaşlı bireylerde aşıya cevabın artırılması amacıyla önerilmektedir. Aşının kontrendikasyonları ve dikkat edilecek uygulama şartları Tablo 4'de gösterilmektedir. Yumurta alerjisi olanlarda dikkatle uygulanması önerilmektedir. Grip aşısı genel olarak güvenli kabul edilen bir aşıdır. Yan etkileri nadir olup, aşılananların \%1'inden azında alerjik reaksiyonlar, aşı yerinde birkaç saatten bir güne kadar süren kızarıklık, kas ağrısı, başağrısı ve hafif ateş gibi bulgular görülebilir $(38,45)$.

\section{Canlı Ínfluenza Aşıları}

Canlı grip aşıları intranazal olarak uygulanmakta olup, her bir burun boşluğuna $0.1 \mathrm{ml}$ olarak (Toplam $0.2 \mathrm{ml}$ ) uygulanır. Hapşırık doz tekrarı gerektirmese de nazal konjesyon varlığg emilimi etkileyeceğinden böyle bir durum varlığında aşı ertelenmeli veya inaktive aşılar tercih edilmelidir. Yumurta alerjisi varlığında bu aşı yapılmamalı ancak aşı yapılması gerekli ise uygun olan herhangi bir lisanslı, tavsiye edilen yaşa uygun influenza aşısı (IIV, RIV4 veya LAIV4) uygulanabilir. Aşının kontrendikasyonları ve dikkat edilecek hususlar Tablo 4'de yer almaktadır. 
Aşı içeriğinde bulunan vahşi tip zayıflatılmış virüs, bağışıklığı baskılanmış kişilerde aktive olarak enfeksiyona neden olabilmektedir. Ancak bu durum çok nadir olsa da influenza komplikasyon riskine sahip kişilere uygulanmamalıdır (48). Canlı aşılar bundan başka $>50$ yaş bireyler, yumurta alerjisi, astım, kronik akciğer, kardiyovasküler (İzole hipertansiyon hariç), renal, hepatik, nörolojik/nöromüsküler, hematolojik veya metabolik hastalığı olan erişkinler ile gebelere uygulanmamalıdır $(45,48)$.

\section{Rekombinan Ínfluenza Aşıları}

Grip aşısı yapımında izole HA elde edildiği, yumurta veya diğer hücre bileşenin içermemesiyle rekombinant aşılar önemli yer oluşturmaktadır. FDA 2013 yılı itibarıyla 18 yaş üzerindeki kişiler için onay vermiştir. $\mathrm{Bu}$ yönüyle yumurta alerjisi olan kişilerde güvenli bir alternatiftir (49,50). Gebelerde ve çocuklarda güvenirliği henüz ortaya konmamıştır. Yan etkileri ve kontrendikasyonları inaktive aşılar gibidir (Tablo 4). Aşılarda bulunan adjuvan ve tiyomerasol miktarları Tablo 4'de gösterilmektedir.

Aşılar 1şıktan korunmalı ve önerilen sıcaklıklarda saklanmalıdır. Genel olarak, grip aşılarının $2-8^{\circ} \mathrm{C}$ arasında $\quad\left(36-46^{\circ}\right.$ de saklanması önerilir) ve dondurulmamalıdır. Dondurulmuş aşı atılmalıdır $(49,54)$.

Ülkemizde influenza aşılarınınm Sosyal Güvenlik Kurumu (SGK) kapsamında geri ödenmesi hususu, Sağlık Uygulama Tebliği’nde (SUT) belirtildiği gibi (2.4.3-B) "Grip aşısı bedeli; 65 yaş ve üzerindeki kişiler ile yaşlı bakımevi ve huzurevinde kalan kişilerin bu durumlarını belgelendirmeleri halinde sağlık raporu aranmaksızın; gebeliğin 2. veya 3. trimestirinde olan gebeler, astım dahil kronik pulmoner ve kardiyovasküler sistem hastalığı olanlar diyabet dahil herhangi bir kronik metabolik hastalığı, kronik renal disfonksiyonu, hemoglobinopatisi veya immün yetmezliği olan veya immunosupresif, tedavi alanlar ile 6 ay, 18 yaş arasında olan ve uzun süreli asetil salisilik asit tedavisi alan çocuk ve adölesanların hastalıklarını/gebelik durumunu belirten sağlık raporuna dayanılarak tüm hekimlerce her Eylül ila Şubat dönemleri içerisinde reçete edildiğinde bir defaya mahsus olmak üzere karşılanır" hükmü doğrultusunda SGK kapsamındaki bireylere geri ödeme yapılmaktadır (55).

Aş1 yaptırmayanlarda veya henüz aşının etkinliğinin oluşmadığı dönem içerisinde kemoproflaksi uygulanabilmektedir. Ancak bu antiviral ilaçlar salgınlar veya maruziyet durumu dışında kullanılmamalıdır. Antiviral proflaksi, grip mevsimi süresince influenza komplikasyonlarının gelişme riski çok yüksek olan $>3$ ay çocuk ve erişkinlerde ve aşının kontendike olduğu veya ulaşılamadığı ya da etkisinin çok düşük beklendiği bireylerde düşünülmelidir. Ayrıca grip ile ilişkili komplikasyonların beklendiği transplant alıcılarında (Hematopoetik kök hücre alıcılarının transplant sonrası 6-12. aylarında ve akciğer transplant alıcılarında) antiviral proflaksi açısından değerlendirilmelidir (53).

\section{KAYNAKLAR}

1. Treanor JJ. Influenza (including avian influenza and swine influenza). In: Bennett JE, Dolin R, Blaser MJ, eds. Principles and Practice of Infectious Diseases. 8th ed. Philadelphia. Elsevier Saunders, 2015:2020-24.

2. Hirsch A. Handbook of Geographical and Historical Pathology. 2nd ed. London. New Sydenham Society, 1883.

3. Crosby AW. Epidemic and Peace 1918. Part IV. Westport CT. Greenwood Press, 1976.

4. Simonsen 1, Clarke MJ, Williamson DW, Stroup DF, Arden NH, Schonberger LB. The impact of influenza epidemics on mortality; introducing a severity index. Am J Pub Health. 1997;(12)87:1944-50. 
5. Kavet J. A perspective on the significance of pandemic influenza. Am J Pub Health. 1977;67(11):1063-70.

6. Glezen WP, Keitel WA, Taber LH, Piedra PA, Clover RD, Couch RB. Age distribution of patients with medically-attended illnesses caused by sequantial variants of influenza $\mathrm{A} / \mathrm{H} 1 \mathrm{~N} 1$ : comparison to age-spesific infection rates, 19781989. Am J Epidemiol. 1991;133(3):296-304.

7. Bhat N, Wright JG, Broder KR, Murray EL, Greenberg ME, Glover MJ et al. Influenzaassociated deaths among children in the United States, 2003-2004. N Eng J Med. 2005;353(24):2559-67.

8. Siston AM, Rasmussen SA, Honein MA, Fry AM, Seib K, Callaghan WM et al. Pandemic 2009 influenza $\mathrm{A}(\mathrm{H} 1 \mathrm{~N} 1)$ virus illness among pregnant women in the United States. JAMA. 2010;303(15):1517-25.

9. Forbes RL, Wark PAB, Murphy VE, Gibson PG. Pregnant woman have attenuated innate interferon responses to 2009 pandemic influenza A virus subtype H1N1. J Infect Dis. 2012;206(5):646-53.

10. Louie JK, Acosta M, Samuel MC, Schechter R, Vugia DJ, Harriman K et al. A novel risc factor for a novel virus: obesity and 2009 pandemic influenza A (H1N1). Clin Infect Dis. 2011;52(3):301-12

11. CDC. 2010-2011 Influenza (Flu) Season. Accessed date, 7 June 2011:

https://www.cdc.gov/flu/pastseasons/1011season.ht m

12. Yan J, Grantham M, Pantelic J, Bueno de Mesquita PJ, Albert B, Liu F et al. Infectious virus in exhaled breath of symptomatic seasonal influenza cases from a college community. Proc Natl Acad Sci USA. 2018;115(5):1081-86.

13. Bischoff WE, Reid T, Russell GB, Peters TR. Transocular entry of seasonal influenza-attenuated virus aerosols and the efficacy of N95 respirators, surgical masks, and eye protection in humans. J Infect Dis. 2011;204(2):193-9.

14. World Health Organization Writing Group, Bell D, Nicoll A, Fukuda K, Horby P, Monto A, Hayden F et al. Non-pharmaceutical interventions for pandemic influenza, international measures. Emerg Infect Dis. 2006;12(1):81-7.

15. Ip DK, Lau LL, Leung NH, Fang VJ, Chan KH, Chu DK et al. Viral shedding and transmission potential of asymptomatic and paucisymptomatic influenza virus infections in the community. Clin Infect Dis. 2017;64(6):736-42.

16. Lau LL, Cowling BJ, Fang VJ, Chan KH, Lau EH, Lipstich $\mathrm{M}$ et al. Viral shedding and clinical illness in naturally acquired influenza virus infections. J Infect Dis. 2010;201(10):1509-16.

17. Leekha S, Zitterkopf NL, Espy MJ, Smith TF, Thompson RL, Sampathkumar P. Duration of influenza A virus shedding in hospitalized patients and implications for infection control. Infect Control Hosp Epidemiol. 2007;28(9):1071-6.

18. Klimov AI, Rocha E, Hayden FG, Shult PA, Roumillat LF, Cox NJ. Prolonged shedding of amantadine-resistant influenzae $\mathrm{A}$ viruses by immunodeficient patients: detection by polymerase chain reaction-restriction analysis. J Infect Dis. 1995;172(5):1352-55.

19. Memoli MJ, Athota R, Reed S, Czajkowsky L, Bristol T, Proudfoot K et al. The natural history of influenza infection in the severely immunocompromised vs nonimmunocompromised hosts. Clin Infect Dis. 2014;58(2):214-24.

20. Lee N, Chan PK, Hui DS, Rainer TH, Wong E, Choi KW et al. Viral loads and duration of viral shedding in adult patients hospitalized with influenza. J Infect Dis. 2009;200(4):492-500.

21. Cohen YZ, Dolin R. Influenza. In: Kasper DL, Fauci AS, Hauser SL et al, eds. Harrison's Principles of Internal Medicine. 19th ed. New York. McGraw Hill Book Company, 2015:1209-14. 
22. Martin CM, Kunin CM, Gottlieb LS, Barnes MW, Lui C. Asian influenza A in Boston, 1957-1958. Observations in thirty-two influenza-associated fatal cases. AMA Arch Intern Med. 1959;103(4):515-31.

23. Chertow DS, Memoli MJ. Bacterial coinfection in influenza: a grand rounds review. JAMA 2013;309(3):275-82.

24. Peltola VT, Murti KG, McCullers JA. Influenza virus neuraminidase contributes to secondary bacterial pneumonia. J Infect Dis 2005;192(2):24957.

25. Schwarzmann SW, Adler JL, Sullivan RJ Jr, Marine WM. Bacterial pneumonia during the Hong Kong influenza epidemic of 1968-1969. Arch Intern Med. 1971;127(6):1037-41.

26. Warren-Gash C, Hayward AC, Hemingway H, Denaxas S, Thomas SL, Timmis AD et al. Influenza infection and risk of acute myocardial infarction in England and Wales: a CALIBER selfcontrolled case series study. J Infect Dis. 2012;206(11):1652-9.

27. Lichenstein R, Magder LS, King RE, King JC Jr. The relationship between influenza outbreaks and acute ischemic heart disease in Maryland residents over a 7-year period. J Infect Dis. 2012;206(6):8217.

28. Paddock CD, Liu L, Denison AM, Bartlett JH, Holman RC, Deleon-Carnes M et al. Myocardial injury and bacterial pneumonia contribute to the pathogenesis of fatal influenza B virus infection. J Infect Dis. 2012;205(6):895-05.

29. Monto AS, Gravenstein S, Elliott M, Colopy M, Schweinle J. Clinical signs and symptoms predicting influenza infection. Arch Intern Med. 2000;160(21):3243-7.

30. Nicholson KG, Kent J, Hammersley V, Cancio E. Acute viral infections of upper respiratory tract in elderly people living in the community: comparative, prospective, population based study of disease burden. BMJ. 1997;315(7115):1060-4.

31. CDC. Information on rapid molecular assays, RTPCR, and other molecular assays for diagnosis of influenza virus infection. Accessed date, 25 September 2018:

http://www.cdc.gov/flu/professionals/diagnosis/mol ecular-assays.htm

32. Bruning AHL, Leeflang MMG, Vos JMBW, Spijker R, de Jong MD, Wolthers KC et al. Rapid Tests for Influenza, Respiratory Syncytial Virus, and Other Respiratory Viruses: A Systematic Review and Meta-analysis. Clin Infect Dis. 2017;65(6):1026-32.

33. CDC. Evaluation of 11 commercially available rapid influenza diagnostic tests-United States, 2011-12. MMWR. 2012;61(43):873-76.

34. CDC. Rapid influenza diagnostic tests. Accessed date, 6 September 2017 :

https://www.cdc.gov/flu/professionals/diagnosis/cli nician_guidance_ridt.htm.

35. Landry ML, Cohen S, Ferguson D. Real-time PCR compared to Binax NOW and cytospinimmunofluorescence for detection of influenza in hospitalized patients. J Clin Virol. 2008;43(2):14851.

36. Covalciuc KA, Webb KH, Carlson CA. Comparison of four clinical specimen types for detection of influenza $\mathrm{A}$ and $\mathrm{B}$ viruses by optical immunoassay (FLU OIA test) and cell culture methods. J Clin Microbiol. 1999;37(12):3971-4.

37. Harper SA, Bradley JS, Englund JA, File TM, Gravenstein S, Hayden FG et al. Seasonal influenza in adults and children-diagnosis, treatment, chemoprophylaxis, and institutional outbreak management: clinical practice guidelines of the Infectious Diseases Society of America. Clin Infect Dis. 2009;48(8):1003-32. 
38. CDC. Rapid diagnostic testing for influenza: Information for health care professionals. Accessed date, 6 September 2017:

http://www.cdc.gov/flu/professionals/diagnosis/rapi dclin.htm.

39. Fiore AE, Fry A, Shay D, Gudareva L, Bresee JS, Uyeki TM et al. Antiviral agents for the treatment and chemoprophylaxis of influenzarecommendations of the Advisory Committee on Immunization Practices (ACIP). MMWR Recomm Rep. 2011;60(1):1-24.

40. Marty FM, Vidal-Puigserver J, Clark C, Gupta SK, Merino E, Garot D et al. Intravenous zanamivir or oral oseltamivir for hospitalised patients with influenza: an international, randomised, doubleblind, double-dummy, phase 3 trial. Lancet Respir Med. 2017;5(2):135-46.

41. CDC. Update: Influenza activity-United States, October 3-December 11, 2010. MMWR. 2010;59(50):1651-5.

42. Beigel JH, Bao Y, Beeler J, Manosuthi W, Slandzicki A, Dar SM et al. Oseltamivir, amantadine, and ribavirin combination antiviral therapy versus oseltamivir monotherapy for the treatment of influenza: a multicentre, double-blind, randomised phase 2 trial. Lancet Infect Dis. 2017;17(12):1255-65.

43. Rodrigo C, Leonardi-Bee J, Nguyen-Van-Tam J, Lim WS. Corticosteroids as adjunctive therapy in the treatment of influenza. Cochrane Database Syst Rev. 2016;3:CD010406.

44. Cowling BJ, Chan KH, Fang VJ, Cheng CK, Fung RO, Wai W et al. Facemasks and hand hygiene to prevent influenza transmission in households: a cluster randomized trial. Ann Intern Med. 2009;151(7):437-46.

45. Grohskopf LA, Sokolow LZ, Broder KR, Walter EB, Fry AM, Jernigan DB. Prevention and Control of Seasonal Influenza with Vaccines: Recommendations of the Advisory Committee on
Immunization Practices-United States, 2018-19 Influenza Season. MMWR. 2018;67(3):1-20.

46. WHO. Accessed date, 22 February 2018. http://www.who.int/influenza/vaccines/virus/recom mendations/201802_recommendation.pdf

47. Erişkin Bağışıklama Rehberi. Türkiye EKMUD, Erişim tarihi: 1 Mayıs 2016: http://ekmud.org.tr/emek/rehberler/1-ekmudrehberleri

48. CDC. Influenza Activity-United States, 2012-13 Season and Composition of the 2013-14 Influenza Vaccine. MMWR. 2013;62(23);473-9.

49. Kroger AT, Duchin J, Vázquez M. Best practices guidance of the Advisory Committee on Immunization Practices (ACIP). Atlanta, GA: US Department of Health and Human Services, CDC; 2017. https://www.cdc.gov/vaccines/hcp/aciprecs/general-recs/downloads/general-recs.pdf

50. Havers FP, Chung JR, Belongia EA, McLean HQ, Gaglani M, Murthy $\mathrm{K}$ et al. Influenza vaccine effectiveness and statin use among adults in the United States, 2011-2017. Clin Infect Dis. 2018 Oct 27. doi: $10.1093 / \mathrm{cid} / \mathrm{ciy} 780$.

51. CDC. The flu season. Atlanta, GA: US Department of Health and Human Services, CDC; 2015. Accessed date, 12 Jully 2018. https://www.cdc.gov/flu/about/season/fluseason.htm

52. Thompsona MG, Pierseb N, Huang QS, Prasad N, Duquea J, Newbernb EC et al. Influenza vaccine effectiveness in preventing influenza-associated intensive care admissions and attenuating severe disease among adults in New Zealand 2012-2015. Vaccine. 2018;36(39):5916-25.

53. Uyeki TM, Bernstein HH, Bradley JS, Englund JA, File TM, Fry AM et al. Clinical Practice Guidelines by the Infectious Diseases Society of America: 2018 Update on Diagnosis, Treatment, Chemoprophylaxis, and Institutional Outbreak Management of Seasonal Influenza. Clinical 
Infectious Diseases. 2018. Accessed date, 19 December 2018, ciy866, https://doi.org/10.1093/cid/ciy866.

54. Udell JA, Zawi R, Bhatt DL, Keshtkar-Jahromi M, Gaughran F, Phrommintikul A et al. Association between influenza vaccination and cardiovascular outcomes in high-risk patients: a meta-analysis. JAMA. 2013:310(16):1711-20. doi: 10.1001/jama.2013.279206.

55. Sosyal Güvenlik Kurumu. http://www.sgk.gov.tr/wps/portal/sgk/tr/kurumsal/ merkez-

teskilati/ana_hizmet_birimleri/gss_genel_mudurlug u/anasayfa_duyurular/18062016_guncel_sut 